\title{
Transnational Terrorism in the West African and the Sahel Region: An Exploration of Causes and Remedies
}

\author{
Assoumi Harouna Abdoul Karim \\ School of International and Public Affairs, Jilin University, China
}

\begin{abstract}
In Africa, while international terrorism has been a salient threat, it has been particularly pronounced in the Horn, West and the predominantly Arabic North. In the Western region of Africa, terror has assumed diverse dimensions. Against this background, this paper seeks to explore the causes and remedies of transnational terrorism in West Africa and the Sahel region. Specifically, the paper analyzes the geopolitical push and pull factors predisposing the West Africa and the Sahel region to transnational terrorism by examining how an inter-play of the state as a domestic player and the state as an international hegemonic pawn engage in actions that serve as a petri dish in which terrorism is cultured and perpetuated. Adopting a qualitative data collection method that relies mainly on secondary and current affairs data on terrorism in the West African region, the paper finds that domestically, terrorism in the West African and the Trans-Sahel region is a product of a decay in state-society relations. This decay a result from narrow definition of the state i.e., as a tool of regime securitization and perpetuation. Over time, this regime securitization and perpetuation agenda result in the neglect of the articulation of the aspirations of the citizenry in public policy which further alienates the state from the people thus allowing the organic maturation of terror. With regard to the state as an international actor, the paper finds that post-September 11 security arrangements that were forged as part of the globalized fight against international terror engendered the militarization of the state which inadvertently occasioned state excesses against the citizenry. The paper calls for the need to address the root causes of terrorism and militarism in the region; an exploration of "bottom-up" local solutions to the challenges of terrorism and violent extremism; enhancing state-society relations in the region and strengthening regional co-operation amongst the states in the West African and the Sahel region.
\end{abstract}

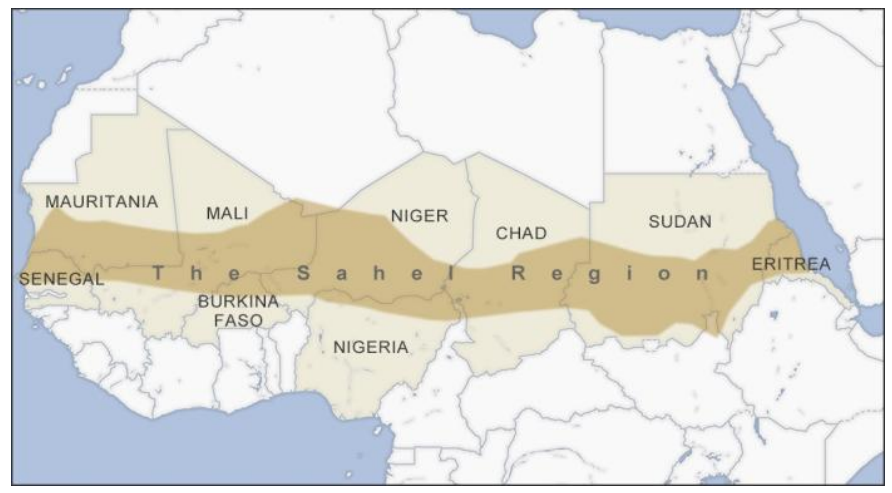

Fig. 1.1 The Sahel Region (Voice of America, 2021)

\section{INTRODUCTION}

$\mathrm{T}$ errorism denotes actions carried out by states, state actors, non-state actors, groups, or individuals which may imperil the life, liberty, property as well as the physical integrity of a people or may cause damage to natural resources, environmental or cultural heritage and where such actions are calculated or intended to intimidate, induce fear, coerce or induce the general public, governmental bodies and/or institution to do or abstain from doing certain actions in order to achieve political objectives or aid in the attainment of specific objectives or valued ideals ${ }^{1}$.

Terrorism may assume domestic or transnational dimensions. On the one hand, domestic or intra-state terrorism denotes terror acts carried out by persons or local groups within the territorial confines of a given state. On the other hand, international or transnational terrorism denotes the acts of terror that are either carried out beyond the territorial confines of the state; or, are carried out by entities that are external to the affected state and whose objective is to advance an extraterritorial cause.

In Africa, while international terrorism has been a salient threat, the scourge has been particularly pronounced in the Horn, West and the predominantly Arabic North. In the Western region of Africa, terror has assumed diverse dimensions particularly regarding to the Southern part of the region i.e., Nigeria and the Sahel region. In lieu of the foregoing, this paper seeks to explore the causes and remedies of transnational terrorism in West Africa and the Sahel region. Specifically, the paper analyzes the geopolitical push and pull factors predisposing the West Africa and the Sahel region to transnational terrorism by examining analyzing how an interplay of the state as a domestic player and the state as an international hegemonic pawn engage in actions that serve as a petri dish in which terrorism is cultured and perpetuated. The paper finally examines viable measures to address transnational terrorism in order to avert the risk of state capture.

Adopting a qualitative data collection method that relies mainly on secondary and current affairs data on

\footnotetext{
${ }^{1}$ Agbiboa, Daniel E. 2013. "(Sp)oiling Domestic Terrorism? Boko Haram and State Response." Peace Review 25 (3): 431-438.
} 
terrorism in the West African region, the paper finds that domestically, terrorism in the West African and the TransSahel region is a product of a decay in state-society relations. This decay result from a narrow definition of the state i.e., as a tool of regime securitization and perpetuation. Over time, this regime securitization and perpetuation agenda results in the neglect of the articulation of the aspirations of the citizenry in public policy which further alienates the state from the people thus allowing the organic maturation of terror. With regard to the state as an international actor, the paper finds that postSeptember 11 security arrangements that were forged as part of the globalized fight against international terror engendered the militarization of the state which inadvertently occasioned state excesses against the citizenry.

The paper is structured into three major sections. The first section reviews and discusses terrorism in Africa in the $21^{\text {st }}$ century by examining its origins and perpetuation from a historical lens. The second section examines the origins and/or causes of terrorism in the West Africa and the Trans-Sahel region. Finally, the last section concludes the paper by outlining the findings of the study and proffering policy recommendations.

\section{LOCATING THE SPATIO-TEMPORAL GEOGRAPHY OF TERRORISM IN WEST AFRICA AND THE SAHEL REGION}

The rise of Pan-Islamic terror has led to the exploitation of openings in African societies to achieve their ends. With recruitment drives centered on marginalized and displaced masses of Islamic communities long victimized by inept or oppressive regimes, Militant Islamic groupings motivated by the global quest by transnational Islamic terror groupings such as al Qaeda to restore the Islamic caliphate to its historical significance have been building momentous militant organizations such as the al Shabaab, al Qaeda in the Islamic Maghreb (AQIM) and Boko Haram².

According to Olivier J. Walther (2017), West Africa and the Sahel region have been ravaged by an exceptional interplay of transnational and trans-regional militarism expressed through armed rebellions, transnational narcotics networks, jihadist insurgencies, protest movements and military putsches. The backdrop to this accumulated violence is a regionalized insecurity environment, which blurs the traditional lines between what is local and global, military and civilian, domestic and international, politics and identity ${ }^{3}$.

As a zone of risk of terrorism, the West African and the Sahel region's risk profile is centered around two critical arcs. One arc straddles across the ungoverned spaces between Mali and Mauritania while the other arc straddles across the region between Guinea-Bissau and Mauritania. To Renard (2010), dynamic threats that shift across West Africa, the

\footnotetext{
${ }^{2}$ Piombo, Jessica R. 2007. Terrorism and U.S. Counter-Terrorism Programs in Africa: An Overview. US Naval Postgraduate School: Monterey, CA.

${ }^{3}$ Walther, Olivier J. 2017. "Wars and Conflicts in the Sahara-Sahel." OECD West Africa Working Paper 10.
}

Sahel and the North Africa tend to be transnational and denationalized. Here, terror groupings such as AQIM, the Boko Haram and the Touaregs exploit ungoverned spaces to perpetuate terrorism and criminal activities ${ }^{4}$.

To Alda and Sala (2014), these ungoverned spaces have also heralded linkages between terror groupings and transnational organized criminalities further complicating counter-terror efforts. The two scholars argue that the intersection between terrorist groups and transnational criminal networks can be defined through coexistence where the distinct groupings coincidentally occupy and operate in the same geographic space at the same time; cooperation where the two groupings temporarily work together driven by the recognition that their mutual interests are both served and/or not least severely threatened; and, convergence where they operate in both criminal and terroristic realms .

This assertion is reiterated by Abderrahmane (2012) who postulates that the region, from Guinea Bissau to Mali, has become a $21^{\text {st }}$ century arena of terrorists and drugs traffickers synergizing their activities and in effect transforming the Sahel into a narco-terrorist zone ${ }^{6}$. To Onuoha and Ezirim (2013), the transnational narcotic criminalities operating in the West African and the Sahel region feed into the terrorist loop across the region ${ }^{7}$. The precarious security situation has been further destabilized due to the proliferation of arms which have found their ways to insurgent and terrorist groups such as the Boko Haram, the al Qaeda in the Islamic Maghreb (AQIM), the Unity Movement for Jihad in West Africa (MUJAO) as well as the Ansar Dineii ${ }^{8}$.

\section{EXPLAINING TERRORISM IN THE WEST AFRICA AND THE SAHEL REGION}

\subsubsection{Terrorism as a Manifestation of State-Societal Distance Decay}

In examining the upsurge of Pan-Islamic terrorism in Africa, Osman Antwi-Boateng (2017), traces the upsurge to various push and pull forces. Antwi-Boateng (2017) postulates that the push forces are contextual circumstances such as youth bulges coupled by high rates of unemployment, authoritarian or tyrannical political systems, human rights

\footnotetext{
${ }^{4}$ Renard, Thomas. 2010. "Terrorism and Other Transnational Threats in the Sahel: What Role for the EU?" Centre on Global Counter-Terrorism Cooperation. September. Accessed April 22, 2020. https://globalcenter.org/wp-

content/uploads/2010/09/renard_policybrief_106.pdf.

${ }_{5}^{5}$ Alda, E., and J. L. Sala. 2014. "Links Between Terrorism, Organized Crime and Crime: The Case of the Sahel Region." International Journal of Security and Development 3 (1).

${ }^{6}$ Abderrahmane, Abdelkader. 2012. "The Sahel: A Crossroads between Criminality and Terrorism." IFRI. October 10. Accessed April 21, 2020. https://www.ifri.org/sites/default/files/atoms/files/actuelleabderrahmane.pdf.

7 Onuoha, Freedom C., and Gerald E. Ezirim. 2013. ""Terrorism" and Transnational Organised Crime in West Africa." Al Jazeera Centre for Studies. June 24. Accessed April 22, 2020.

${ }^{8}$ Op. cit., Abderrahmane 2012. See also, Sour, Lotfi. 2015. "The Strategy of Securitization in African Sahel: Regional Arrangements and Transnational Security Challenges." International Journal of Political Science 1 (2): 6-18.
} 
abuses, kleptocratic regimes and institutional failure that predispose people in Islamic societies to embrace violent jihadist ideology. On the other hand, pull factors denotes the value proposition that terror or jihadi movements proffer in order to attract the people to their cause and course. These include the lure of martyrdom and the rewards of the afterlife, radical Islamic ideology, influences of radical Madrassas, humanitarian networks, propaganda and the provision of a "purpose and mission". Antwi-Boateng (2017) argues that the interplay of these factors cultivate terrorism creating an existential threat to the Westphalian state system and particularly in countries where institutions are weak leading to security conundrums ${ }^{9}$.

The petri dish unto which terrorism in the region is cultured can be traced to the entrenchment of violence and militarism in the DNA of socio-political relations in the region. According to Agbiboa (2013), most of the countries in the region have been subject to prolonged periods of military rule. In Nigeria for instance, the military ruled for three quarters of the country's first forty years of the postindependence era. This was aptly captured by eminent Nigerian political scientist, Claude Ake, who postulated that the postcolonial state in Nigeria has been largely defined as an apparatus of violence which due to poor state-society relations had an extremely narrow base in social forces while compliance was largely underlined by coercion. This militarism in socio-political relations has permeated a majority of Nigeria's political formations and resistant movements including the Biafra Secessionist movement and the Boko Haram ${ }^{10}$.

According to Blomberg, et al. (2011) who assess the nexus between economic growth, resource exploitation and terrorism in sub-Saharan Africa, the terrorist-oriented fragility of sub-Saharan African countries has been on a rise in the $21^{\text {st }}$ century occasioned by a resource curse. Their findings are the most terror-oriented fragility emanates largely from primary fuel exporters such as Nigeria, the Central African Republic, Mali and Niger. They attribute this phenomenon to the fact that primary fuel exporters have been sluggish in investing in counter-terrorism policies ${ }^{11}$.

The aftermath of the Arab Spring has also been pointed out as a key enabler of terror in West Africa and the Sahel region. In examining the arms and conflict dynamics in Libya and in the Sahara-Sahel Region, Strazzari and Tholens (2014) postulate that the civil war in Libya heralded a subsequent proliferation of weapons in the broader Sahel and West African region owing to changing conditions of the availability of weapons. As weapons became more readily

\footnotetext{
9 Antwi-Boateng, Osman. 2017. "The Rise of Pan-Islamic Terrorism in Africa: A Global Security Challenge." Politics \& Policy 45 (2): 253-284.

${ }^{10}$ Agbiboa, Daniel E. 2013. "(Sp)oiling Domestic Terrorism? Boko Haram and State Response." Peace Review 25 (3): 431-438

${ }^{11}$ Blomberg, Brock, Nzinga H. Broussard, and Gregory D. Hess. 2011. "New wine in old wineskins? Growth, terrorism and the resource curse in subSaharan Africa." European Journal of Political Economy 27 (1): S50-S63.
}

available to fighters, they gave birth to a new trajectory that veered from the initial process of democratizing Libya. This started with the fragmentation of the revolutionary force thus leading to insecurity. In turn, the insecurity led to unaccountable small arms and light weapons which proliferated the weaponry to Sahelian insurgencies as well as armed groups as far south as West Africa. This proliferation of small arms and light weapons rekindled and/or altered conflicts in the broader Sahel and West African region thus creating permissive conditions for the perpetuation of terror ${ }^{12}$.

These sentiments are reiterated by Nathaniel Danjibo who examines the aftermath of the Arab Spring and the security implications this phenomenon had for security in the Sahel. Danjibo postulates that the Arab Spring was a disaster for fragile states in West Africa and the Sahel region which had long grappled with attendant governance deficits. By creating opportunities as well as openings for the proliferation of small arms and light weapons as well as threat inflation occasioned by the spillover of conflicts and ideas, this created the platform for terror actors to penetrate the Sahel ${ }^{13}$.

In extrapolating the Libyan crisis' repercussions in the West African region and the Sahel and specifically Niger, Mali and Nigeria, Abdelhak Bassou and Ihssane Guennoun postulate that terror groupings and arms traffickers have been converging in southern Libya fueling violence and radicalism in northern Nigeria, Mali and Niger. Furthermore, the two scholars postulate, the Libyan crisis has also revived rebellions by Touareg separatists ${ }^{14}$.

To Valeria Rosato (2016), The threat posed by Islamist terrorism in West Africa and the Sahel region is a product of destabilizing factors located in the fragile states in the region such as weak and corrupt state apparatuses. This has fueled transnational criminality, disillusionment of diverse societal groupings on the viability of the state as well as separatist demands. As such, the intersection between terrorism and organized crime in West Africa and the Sahel region largely emanate from for terror groupings operating in the region, crime has been a means for producing resources that will be deployed to achieve their Pan-Islamic ideological goals. Where such groupings are distinct, their relationships and/or alliances are pronounced under ungoverned spaces occasioned by state failure or weakness of state institutions thus limiting their geographical or institutional reach. In such instances, nouveau terrorist groupings enjoy more freedom of

\footnotetext{
${ }^{12}$ Strazzari, Francesco, and Simone Tholens. 2014. "Tesco for Terrorists' Reconsidered: Arms and Conflict Dynamics in Libya and in the Sahara-Sahel Region." European Journal on Criminal Policy and Research 20: 343-360.

${ }^{13}$ Danjibo, Nathaniel D. 2013. "The Aftermath Of The Arab Spring And Its Implication For Peace And Development In The Sahel And Sub-Saharan Africa." Strategic Review for Southern Africa 35 (2): 16-34.

${ }^{14}$ Bassou, Abdelhak, and Ihssane Guennoun. 2017. The Sahel faced with Al Qaeda and Daesh trends: What are possible outcomes? January. https://www.policycenter.ma/sites/default/files/OCPPCPB1701vEn.pdf.
} 
operation and predatory capitalism where the local economy has long been under the control of criminal groups ${ }^{15}$.

In Nigeria, while the Boko Haram terror group operating in the Nigerian north eastern region has been the most threatening and complex security issue in Nigeria, the counter-terror response, underpinned by American war on terror policies, has adopted "hard politics" coupled with military mobilization. Spending heavily on defense to upgrade military hardware and train personnel as well as boosting its strategic importance in the "global war on terror", this approach has failed to contain Boko Haram. Rather, it has the unwarranted loss of lives while further perpetuating the decay in state-society relations ${ }^{16}$.

\subsubsection{Hegemonic Security Arrangements and the Militarization of the Socio-Political Relations}

Terror in West African and the Sahel region has also been traced to the $21^{\text {st }}$ century global war on terror. According to Kimunguyi who explores the role of bilateral and multilateral actors such as the United Nations, the European Union and the United States in propping up West African and Sahelian states in enhancing their capacities to counter terrorism, while significant inroads have been made to develop coherent counterterrorism approaches, the challenge with this approach is that it has been centred on short-term security and law enforcement efforts. As such, longer-term measures to confront the root conditions that ferment terrorism have been negatively affected. The net effect has been an increase in Islamic radicalization, competing for national priorities, lack of a state capacity to counter both the root conditions of terror and terrorism and political sensitivity to counter-terrorism ${ }^{17}$.

To Lyman, West African and Sahelian states have hailed American help in securitizing their ungoverned spaces. These ungoverned spaces i.e., the swathe of geography in Northern Nigeria, the Sahel, the Gulf of Guinea cumulatively interlink to form a formidable geography with limited government presence occasioned by both state absence and abstinence. It is this area that has become war arena in the anti-terror drive as America and her allied in West Africa and the Sahel seek to deny that space to terror groups such as the Touaregs; the al-Qaeda in the Islamic Maghreb, as well as a retinue of other terrorist groupings domiciled in the region ${ }^{18}$.

\footnotetext{
${ }^{15}$ Rosato, Valeria. 2016. "“Hybrid Orders" between Terrorism and Organized Crime: The Case of Al Qaeda in the Islamic Maghreb." African Security 9 (2): 110-135.

${ }^{16}$ Oyewole, Samuel. 2013. "Boko Haram and the challenges of Nigeria's war on terror." Defense \& Security Analysis 29 (3): 253-262.

17 Kimunguyi, Patrick. 2011. "Terrorism and Counter terrorism in East Africa."

https://s3.amazonaws.com/academia.edu.documents/30183043/terrorismcounter-terrorism-eafrica-pk.pdf.

${ }^{18}$ Lyman, N. 2009. "The War on Terrorism in Africa." In Africa in World Politics, edited by John Harbeson and Donald Rothchild. Boulder, CO: Westview Press.
}

Unlike other countries which have balanced the need for new security legislations with a preservation of liberties and through active diplomacy to contain terror in their near abroad, West African and Sahelian states have used the terrorist threat to not only solidify anti-democratic and suppression practices and policies but also to solidify American support for their anti-terrorist policies. Lamentably, West African and Sahelian states still face unrest from within their ungoverned spaces. According to Lyman, the American anti-terrorism programs which have heralded unprecedented militarization of American policy in Africa has largely served to increase the militarization of dissidence and resistance while prosecuting the case for violent resistance of America's anti-terror and anti-Islamic policies in Africa ${ }^{19}$.

Owing to the perpetuation of criminality in West Africa and the Sahel, Lyman contends, the danger in America's counter-terror policies in West Africa and the Sahel is that the steps these policies promote are precisely those that produce the strongest reaction from those groups who do not pursue terror but have long lived on smuggling and similar activities. These disruptions have largely produced support as well as openings for influence to terror groupings such as the al-Qaeda in the Islamic Maghreb and the Boko Haram who straddle across the region. In the second decade of the $21^{\text {st }}$ century for instance, the most serious terror threats in the region have either come from disaffected minority groups such as the Touaregs in Mali who facing decades of underdevelopment through state absence and abstinence coupled by a mix of poverty and discrimination have resorted to running long-standing networks of criminality. As such, these groups abhor interference in their illicit economic activities and would more readily than not resort to terrorism ${ }^{20}$.

To Sylvain Medessoukou (2018), the evolution of the international security paradigm occasioned by the global war on terror in the wake of the September $11^{\text {th }}$ terrorist attacks heralded the involvement of international actors across the globe. Owing to colonial ties and Area Boy diplomatic forays in the West African and the Sahel region, France was immensely involved in rebuilding and reshaping the security across the terror ravaged region. Rather than cure the challenge of Islamic terrorism, the French involvement in the region further exacerbated the contradictions that exacerbated the challenge posed by Islamic radicalization ${ }^{21}$.

The hegemonic forays in Africa can also be traced to the $21^{\text {st }}$ century scramble for African with the realization that Africa is the new hinterland in Mackinder's fashion. According to Ifeka (2010), at the height of this scramble has been the United States, the Chinese and the European Union who've been competing to control strategic resources such as

\footnotetext{
${ }^{19}$ Op. cit., Lyman, 2009

${ }^{20} \mathrm{Ibid}$

${ }^{21}$ Medessoukou, Sylvain. 2018. "The Foreign Security Policy in Africa: France in Sahel Region." American Scientific Research Journal for Engineering, Technology, and Sciences 47 (1): 156-165.
} 
oil, bauxite and uranium in the West African and the Sahel region. As such, the prosecution of the war on terror has been pursued as a means to securitize 'dangerous' West African Muslim states in order to manoeuvre leases to exploit resources vital to American and European union energy security needs as well as capital accumulation. In response, Islamic youths in the West African and the Sahel region, responding to the call to the growing youth militancy have been mobilizing around ethnicity and Islamic reformism as they seek to coerce the ruling class's into sharing the 'dividends of democracy' 22 .

Daniel Agbiboa (2013) is of the view that the West African region and the Sahel. In examining how the region has become a sphere of influence for Pan-Islamic religious groupings by examining Boko Haram and the state responses, Agbiboa (2013) opines that the states' responses, rather than stemming the tidal wave of terror have facilitated in oiling it. Hinging the rationality of the study on the significant increase in the number and level of intensity of terrorist incidents in the $21^{\text {st }}$ century, Agbiboa (2013) laments the relative ineffectiveness of the many transnational terrorism clean-up ventures, and particularly those mooted as part of the Global War on Terror mooted in the wake of the September $11^{\text {th }}$ attack in the United States in $2001^{23}$.

Coupled by elite appropriation of rental incomes from 'traditional' community owned strategic resources as oil, gas, gold, bauxite, uranium, and water, the under-class in the West African region and the Sahel have over the years been radicalized to a situation of readiness to sacrifice their lives in fighting the war machine of the repressive State. In Islamic societies, under-class devout Muslim youth have largely been driven by a desire for good governance driven not by secular terms as espoused in the overriding democratic tenets of the post-Cold War globalized world but rather in accordance to Quranic precepts ${ }^{24}$.

\section{CONCLUSION AND RECOMMENDATIONS}

\subsubsection{Conclusion}

West African and the Sahelian states have been ravaged the rise of Pan-Islamic terror has led to the exploitation of openings in African societies to achieve their ends. To compound matters further, this phenomenon has been compounded by an exceptional interplay of transnational and trans-regional militarism expressed through armed rebellions, transnational narcotics networks, jihadist insurgencies, protest movements and military putsches. The

\footnotetext{
${ }^{22}$ Ifeka, Caroline. 2010. "War on 'Terror': AFRICOM, the Kleptocratic State and Under-Class Militancy in West Africa-Nigeria." Concerned African Scholars 85: 30-49.

${ }^{23}$ Agbiboa, Daniel E. 2013. "(Sp)oiling Domestic Terrorism? Boko Haram and State Response." Peace Review 25 (3): 431-438.

${ }^{24}$ Ibid, Ifeka 2010. See also, Lewandowsky, S., W. G. K. Stritzke, A. M. Freund, K. Oberauer, and J. I. Krueger. 2013. "Misinformation, disinformation, and violent conflict: From Iraq and the "War on Terror" to future threats to peace." American Psychologist 68 (7): 487-501.
}

backdrop to this accumulated violence is a regionalized insecurity environment centered around two critical arcs.

This paper finds that the manifestation of terror is a function of state societal distance decay in that, societies experiencing contextual circumstances such as youth bulges coupled by high rates of unemployment, authoritarian or tyrannical political systems, human rights abuses, kleptocratic regimes and institutional failure in a state that is non-receptive to the articulation of grievances withdraw their legitimacy from the state. This legitimacy is vested in fulcrums beyond the state's social control. Over time, this is manifested in the form of rebellions.

To enhance its social control in the wake of poor state-society relations, these states pursue societal compliance through coercion. Furthermore, poor state societal relations in geographies beyond the region such as Libya have led to the proliferation of weapons in the broader Sahel and West African region owing to changing conditions of the availability of weapons. To this end therefore, the threat posed by Islamist terrorism in West Africa and the Sahel region is a product of destabilizing factors located in the fragile states in the region such as weak and corrupt state apparatuses.

This phenomenon is perpetuated further by the militarization of the state as epitomized by the $21^{\text {st }}$ century hegemonic security arrangements articulated in the American led war on terrorism. This counter-terror war has been exploited to respond to the terrorist threat and to solidify antidemocratic and suppression practices and policies. The engendered militarization of counter-terrorism contrary to its objectives, increased the militarization of dissidence and resistance while prosecuting the case for violent resistance of America's anti-terror and anti-Islamic policies in Africa.

\subsubsection{Policy Recommendations}

The threat inflation from terrorism in the West African and the Sahel region has increased the vulnerability of the economies as well as political stability of states ravaged by terrorism in the region. Heterogeneous society also face considerable risk considering their propensity to break down along sectarian lines. In lieu of the foregoing, enhancing the West African and the Sahel region's resilience is of paramount importance if the region is to tackle terrorism. This paper recommends that; first, there is an urgent need to address the root causes of terrorism and militarism in the region is also pivotal in ending terrorism. Terrorism and violent extremism do not rise from a vacuum. Grievances tend to arise where the state and its institution routinely violated human rights and where ethos of good governance are relegated to the periphery Issues like suppression of human rights, authoritarian regimes, poverty, marginalization should be addressed. Focus should be placed on embracing diplomatic means to preventing, managing and resolving societal conflicts.

Secondly, there is a need to move away from the militarized war on terror. A militarized approach to security 
tends to encourage authoritarianism and the suppression of rights. This tends to attract militarized resistance from the citizenry. Furthermore, the American "one-size-fits-all" approach to terrorism in the post-September 11 era has largely created conditions conducive to terrorism rather than inhibiting them. As such, West African and the Sahelian states should also explore and encourage "bottom-up" homegrown responses to the challenges posed by terrorism and violent extremism across the region. To this end therefore, there is a need for affected communities to decentralize counter-terror efforts in order to reflect local realities.

Thirdly, enhancing state society relations in the region is important in order to reduce frictions between the state and state. It is also imperative of the state to shy away from militarizing the state but rather address the fragility of the state and its institutions by strengthening them and addressing their weaknesses, encouraging a robust civil society as well as promoting sustainable development in order to combat poverty, marginalization and societal inequalities as building blocks to a durable peace. This will work towards restoring the legitimacy of governments and in establishing inclusive governance solutions in the ungoverned spaces of West Africa and the Sahel region.

West African and Sahelian states must also be cognizant of the pivotal role played by youths in terrorism who are victims of terror and also serve as perpetrators. Harnessing the energy that comes with youthfulness, their creativity and power in young West Africans and Sahelians is critical in building up the resilience of these societies not only in combating terrorism but also in building more peaceful, just and inclusive societies.

There is a need to strengthen regional co-operation amongst the states in the West African and the Sahel region. The terror threat in the region transcends the state level. To this end therefore, there is a need to reassess how states respond as a region. National and multilateral actors such as the United Nations, the African Union, the Economic Community of West African States and the G5 Sahel should thus forge a united front of this dragon is to be slain. West African and the Sahelian states should forge a common effort in engagements at the sub-regional and regional levels in order to not only counter terrorism and violent extremism in the region by sharing intelligence and conducting joint counter-terrorism operations but also to improve state-society relations; disarm, demobilize and reintegrate terror operatives; undertake security sector reforms, as well as build on longterm measures such as addressing the causes of terror and violent extremism and embarking on sustainable development processes.

\section{REFERENCES}

[1] Abderrahmane, Abdelkader. 2012. "The Sahel: A Crossroads between Criminality and Terrorism." IFRI. October 10. Accessed April 21, 2020. https://www.ifri.org/sites/default/files/atoms/files/actuelleabderrah mane.pdf.
[2] Agbiboa, Daniel E. 2013. "(Sp)oiling Domestic Terrorism? Boko Haram and State Response." Peace Review 25 (3): 431-438.

[3] Alda, E., and J. L. Sala. 2014. "Links Between Terrorism, Organized Crime and Crime: The Case of the Sahel Region." International Journal of Security and Development 3 (1).

[4] Antwi-Boateng, Osman. 2017. "The Rise of Pan-Islamic Terrorism in Africa: A Global Security Challenge." Politics \& Policy 45 (2): 253-284.

[5] Bassou, Abdelhak, and Ihssane Guennoun. 2017. The Sahel faced with Al Qaeda and Daesh trends: What are possible outcomes? January. https://www.policycenter.ma/sites/default/files/OCPPCPB1701vEn.pdf.

[6] Blomberg, Brock, Nzinga H. Broussard, and Gregory D. Hess. 2011. "New wine in old wineskins? Growth, terrorism and the resource curse in sub-Saharan Africa." European Journal of Political Economy 27 (1): S50-S63.

[7] Danjibo, Nathaniel D. 2013. "The Aftermath Of The Arab Spring And Its Implication For Peace And Development In The Sahel And Sub-Saharan Africa." Strategic Review for Southern Africa 35 (2): $16-34$.

[8] Ifeka, Caroline. 2010. "War on 'Terror': AFRICOM, the Kleptocratic State and Under-Class Militancy in West AfricaNigeria." Concerned African Scholars 85: 30-49.

[9] Kimunguyi, Patrick. 2011. "Terrorism and Counter terrorism in East Africa." https://s3.amazonaws.com/academia.edu.documents/30183043/terr orism-counter-terrorism-eafrica-pk.pdf.

[10] Lewandowsky, S., W. G. K. Stritzke, A. M. Freund, K. Oberauer, and J. I. Krueger. 2013. "Misinformation, disinformation, and violent conflict: From Iraq and the "War on Terror" to future threats to peace." American Psychologist 68 (7): 487-501.

[11] Lyman, N. 2009. "The War on Terrorism in Africa." In Africa in World Politics, edited by John Harbeson and Donald Rothchild. Boulder, CO: Westview Press.

[12] Medessoukou, Sylvain. 2018. "The Foreign Security Policy in Africa: France in Sahel Region." American Scientific Research Journal for Engineering, Technology, and Sciences 47 (1): 156165.

[13] Onuoha, Freedom C., and Gerald E. Ezirim. 2013. ""Terrorism" and Transnational Organised Crime in West Africa." Al Jazeera Centre for Studies. June 24. Accessed April 22, 2020.

[14] Oyewole, Samuel. 2013. "Boko Haram and the challenges of Nigeria's war on terror." Defense \& Security Analysis 29 (3): 253262.

[15] Piombo, Jessica R. 2007. Terrorism and U.S. Counter-Terrorism Programs in Africa: An Overview. US Naval Postgraduate School: Monterey, CA.

[16] Renard, Thomas. 2010. "Terrorism and Other Transnational Threats in the Sahel: What Role for the EU?" Centre on Global Counter-Terrorism Cooperation. September. Accessed April 22, 2020. content/uploads/2010/09/renard_policybrief_106.pdf.

[17] Rosato, Valeria. 2016. "'Hybrid Orders" between Terrorism and Organized Crime: The Case of Al Qaeda in the Islamic Maghreb." African Security 9 (2): 110-135.

[18] Sour, Lotfi. 2015. "The Strategy of Securitization in African Sahel: Regional Arrangements and Transnational Security Challenges." International Journal of Political Science 1 (2): 6-18.

[19] Strazzari, Francesco, and Simone Tholens. 2014. "Tesco for Terrorists' Reconsidered: Arms and Conflict Dynamics in Libya and in the Sahara-Sahel Region." European Journal on Criminal Policy and Research 20: 343-360.

[20] Walther, Olivier J. 2017. "Wars and Conflicts in the SaharaSahel." OECD West Africa Working Paper 10. 